\title{
Ammonia inhibition on hydrogen enriched anaerobic digestion of manure under mesophilic and thermophilic conditions
}

Wang, Han; Zhang, Yifeng; Angelidaki, Irini

Published in:

Water Research

Link to article, DOI:

10.1016/j.watres.2016.09.006

Publication date:

2016

Document Version

Peer reviewed version

Link back to DTU Orbit

Citation (APA):

Wang, H., Zhang, Y., \& Angelidaki, I. (2016). Ammonia inhibition on hydrogen enriched anaerobic digestion of manure under mesophilic and thermophilic conditions. Water Research, 105, 314-319.

https://doi.org/10.1016/j.watres.2016.09.006

\section{General rights}

Copyright and moral rights for the publications made accessible in the public portal are retained by the authors and/or other copyright owners and it is a condition of accessing publications that users recognise and abide by the legal requirements associated with these rights.

- Users may download and print one copy of any publication from the public portal for the purpose of private study or research.

- You may not further distribute the material or use it for any profit-making activity or commercial gain

- You may freely distribute the URL identifying the publication in the public portal

If you believe that this document breaches copyright please contact us providing details, and we will remove access to the work immediately and investigate your claim. 


\section{Accepted Manuscript}

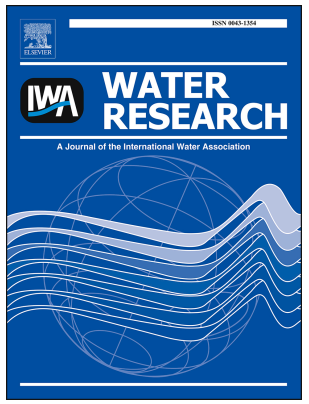

Ammonia inhibition on hydrogen enriched anaerobic digestion of manure under mesophilic and thermophilic conditions

Han Wang, Yifeng Zhang, Irini Angelidaki

PII: $\quad$ S0043-1354(16)30684-4

DOI: $\quad$ 10.1016/j.watres.2016.09.006

Reference: WR 12345

To appear in: Water Research

Received Date: 2 April 2016

Revised Date: 6 September 2016

Accepted Date: 6 September 2016

Please cite this article as: Wang, H., Zhang, Y., Angelidaki, I., Ammonia inhibition on hydrogen enriched anaerobic digestion of manure under mesophilic and thermophilic conditions, Water Research (2016), doi: 10.1016/j.watres.2016.09.006.

This is a PDF file of an unedited manuscript that has been accepted for publication. As a service to our customers we are providing this early version of the manuscript. The manuscript will undergo copyediting, typesetting, and review of the resulting proof before it is published in its final form. Please note that during the production process errors may be discovered which could affect the content, and all legal disclaimers that apply to the journal pertain. 

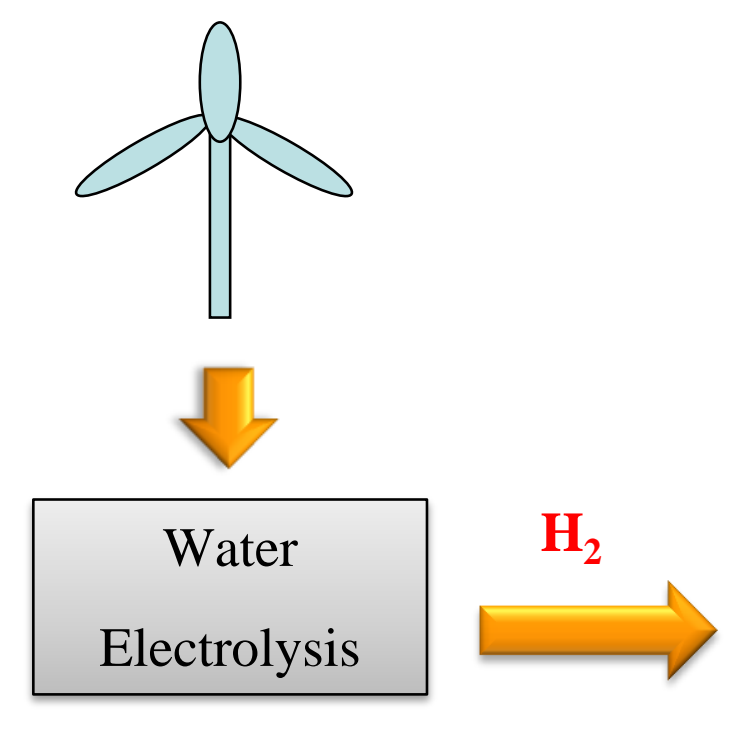

Ammonia rich waste streams

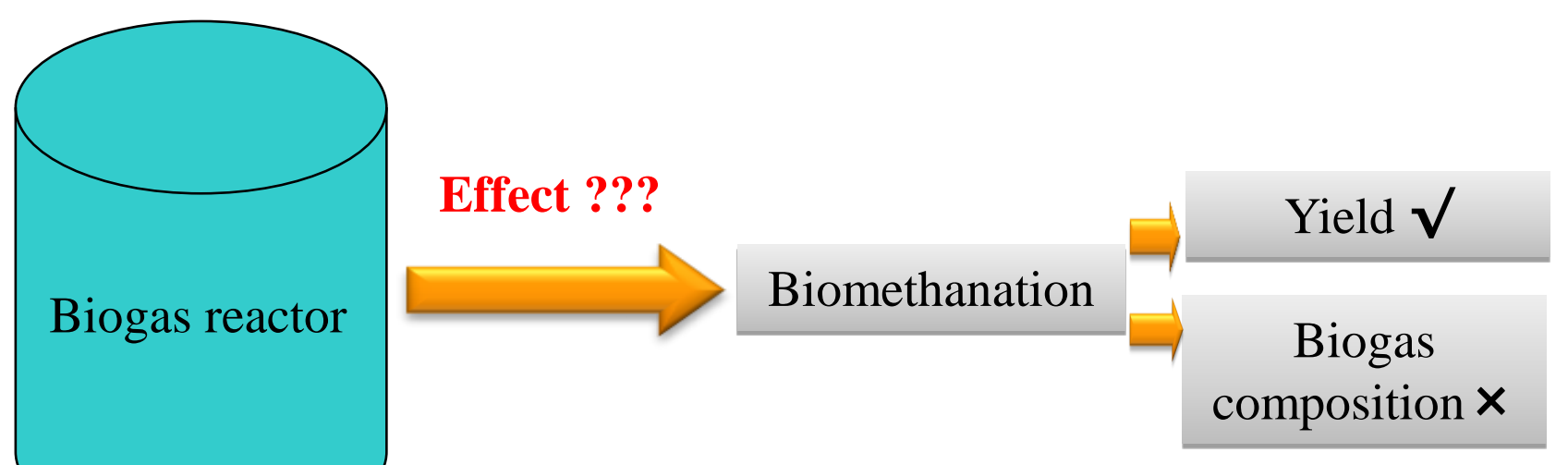

Thermophilic/Mesophilic 
1 Submission to Water Research

2 Ammonia inhibition on hydrogen enriched anaerobic digestion of manure un-

3

4

5

6

7

8

9

10

11

12

13

14

15

16

17

18

19

20

21

22

23

1

2

3

4

15

17

8

9

0 der mesophilic and thermophilic conditions

Han Wang, Yifeng Zhang*, and Irini Angelidaki

Department of Environmental Engineering, Technical University of Denmark, Miljoevej B113, DK 2800 Kgs. Lyngby, Denmark;

*Corresponding Author: Yifeng Zhang

Department of Environmental Engineering, Technical University of Denmark, DK2800 Kgs. Lyngby, Denmark, e-mail address: yifz@env.dtu.dk 
24 Abstract

25 Capturing of carbon dioxide by hydrogen derived from excess renewable energy

26 (e.g., wind mills) to methane in a microbially catalyzed process offers an attractive

27 technology for biogas production and upgrading. This bioconversion process is cat-

28 alyzed by hydrogenotrophic methanogens, which are known to be sensitive to am-

29 monia. In this study, the tolerance of the biogas process under supply of hydrogen,

30 to ammonia toxicity was studied under mesophilic and thermophilic conditions.

31 When the initial hydrogen partial pressure was $0.5 \mathrm{~atm}$, the methane yield at high

32 ammonia load $\left(7 \mathrm{~g} \mathrm{NH}_{4}^{+}-\mathrm{N} \mathrm{L}^{-1}\right)$ was $41.0 \%$ and $22.3 \%$ lower than that at low am-

33 monia load $\left(1 \mathrm{~g} \mathrm{NH}_{4}^{+}-\mathrm{N} \mathrm{L}^{-1}\right)$ in mesophilic and thermophilic condition, respective-

34 ly. Meanwhile no significant effect on the biogas composition was observed. More-

35 over, we found that hydrogentrophic methanogens were more tolerant to the ammo-

36 nia toxicity than acetoclastic methanogens in the hydrogen enriched biogas produc-

37 tion and upgrading processes. The highest methane production yield was achieved

38 under 0.5 atm hydrogen partial pressure in batch reactors at all the tested ammonia

39 levels. Furthermore, the thermophilic methanogens at 0.5 atm of hydrogen partial

40 pressure were more tolerant to high ammonia levels $\left(\geq 5 \mathrm{~g} \mathrm{NH}_{4}{ }^{+}-\mathrm{N} \mathrm{L}^{-1}\right)$, compared

41 with mesophilic methanogens. The present study offers insight in developing re-

42 sistant hydrogen enriched biogas production and upgrading processes treating am-

43 monia-rich waste streams.

44 Keywords

45 Anaerobic digestion; Ammonia inhibition; Hydrogenotrophic methanogens; Hydro46 gen; Wastewater treatment 


\section{Introduction}

Anaerobic digestion (AD) is a sustainable technology that has been used for the treatment of various waste streams such as animal manure, food waste and sludge. However, AD treatment of the substrates containing high total ammonia (ammonium ion and free ammonia) concentration can be seriously inhibited by the ammonia which is produced during the biodegradation of proteins, urea and nucleic acids. There are two principal forms of inorganic ammonia nitrogen in aqueous solution: Ammonium ion $\left(\mathrm{NH}_{4}{ }^{+}\right)$and free ammonia $\left(\mathrm{NH}_{3}\right) . \mathrm{NH}_{3}$ has been considered to be the main inhibitor (Rajagopal et al., 2013; Yenigün \& Demirel, 2013). $\mathrm{NH}_{3}$ molecules diffuse into the microbes' cells freely which can cause proton imbalance, increase maintenance energy requirements, change intracellular $\mathrm{pH}$ and inhibit specific enzyme reactions (Gallert et al., 1998; Sprott \& Patel, 1986). $\mathrm{NH}_{3}$ concentration mainly depends on temperature, $\mathrm{pH}$ and total ammonia concentration in anaerobic digestion process (Hafner \& Bisogni, 2009). For example, the concentration of $\mathrm{NH}_{3}$ increases with an increase in $\mathrm{pH}$ and/or temperature which causes the enhanced ammonia toxicity on the AD process (Nielsen \& Angelidaki, 2008).

The AD process can be described by four distinctive steps namely: hydrolysis, acidogenesis, acetogenesis and methanogenesis. In detail, with the exception of the initial solubilisation of complex particulate material, methanogenesis seems to be the rate-limiting step. Moreover methanogens are the most vulnerable to ammonia compared to other groups of microorganisms involved in AD process (Angelidaki et al., 2011). There are two distinct methanogenic pathways for converting acetate to methane, which has been well described in previous studies (Fotidis et al., 2013; Wang et al., 2015). There are many papers referring on the sensitivity of the meth- 
71 anogens to ammonia (Fotidis et al., 2013). It was reported that acetoclastic methanogens (i.e. Methanosarcinaceae spp. and Methanosaetaceae spp.) are more vul-

73 nerable to ammonia toxicity compared to hydrogenotrophic methanogens (i.e.

74 Methanomicrobiales spp., Methanococcales spp., Methanocellales spp., Methano75 bacteriales spp. and Methanopyrales spp.) (Angelidaki \& Ahring, 1993; Yenigün \& 76 Demirel, 2013).

77 Recently, an innovative AD process, which introduces hydrogen produced by water 78 electrolysis using excess electricity from wind mill into anaerobic digester and sub79 sequently converts it together with carbon dioxide in biogas into methane has been 80 developed for simultaneous $\mathrm{H}_{2}$ utilization and in-situ biogas upgrading (mainly re81 fers to reduction of $\mathrm{CO}_{2}$ content), giving synergistic advantages for both wind mills 82 and biogas plants. (Deng \& Hägg, 2010; Luo \& Angelidaki, 2012; Luo et al., 2012). 83 Such process has several advantages over conventional AD process: (1) low cost for 84 further biogas upgrading since $\mathrm{CO}_{2}$ content was reduced; (2) increase of methane 85 production; (3) fully use of the wind mill capacity. Though promising, the $\mathrm{H}_{2}$ en86 riched AD process is just emerging from a technology perspective. There are sever87 al challenges to be addressed for being able to develop a sustainable feasible technology. One important aspect is the resistance of the process to ammonia inhibition, 89 which is the very aspect that is unclear so far. Considering that most of the feed90 stocks (e.g., cattle manure) in biogas plants (especially in Denmark) contain high 91 level of ammonia, it is of outmost important to reveal the sensitivity of the process 92 to high level of ammonia in order to accelerate the wide application of the technol93 ogy. The outcome of such investigation will also help to find suitable strategy to 94 counteract the ammonia inhibition. 
95 During this process, enrichment of hydrogenotrophic methanogenic cultures in an-

96 aerobic biogas reactors is occurring. In Luo and Angelidaki (2012)'s study, hydro-

97 gen was injected into anaerobic reactors to achieve a hydrogen partial pressure of

$980.8 \mathrm{~atm}$. After two months cultivation with $\mathrm{H}_{2}$, the hydrogenotrophic methanogenic

99 activities increased to $198 \mathrm{~mL} \mathrm{CH}_{4}(\mathrm{~g} \text { VSS h})^{-1}$ under mesophilic and $320 \mathrm{~mL} \mathrm{CH}_{4}$

$100 \mathrm{~g} \mathrm{VSS} \mathrm{h}^{-1}$ under thermophilic condition, from around $10 \mathrm{~mL} \mathrm{CH}_{4}(\mathrm{~g} \mathrm{VSS} \mathrm{h})^{-1}$ of

101 the original inoculum. This indicated that hydrogenotrophic methanogens were suc-

102 cessfully enriched by long term injection of hydrogen. Thus, it would be obvious to

103 assume that this process would be more resistant or tolerant to ammonia toxicity

104 due to the enrichment of hydrogenotrophic methanogenesis compared to the con-

105 ventional AD processes (Luo \& Angelidaki, 2013b; Luo \& Angelidaki, 2012; Luo

106 et al., 2012). So far, information about the effect of ammonia toxicity on this inno-

107 vative AD process is still lacking. Therefore, in this study, the effect of different

108 ammonia levels on hydrogen enriched biogas upgrading process (different hydrogen

109 partial pressure were included in the current study) in anaerobic reactors at both

110 mesophilic and thermophilic temperature was explored.

\section{2. Materials and methods}

\section{$112 \quad 2.1$ Inoculum and feedstock}

113 The mesophilic and thermophilic inoculum were obtained from mesophilic and

114 thermophilic anaerobic reactors in Hashøj Biogas plant (Denmark) and Snertinge

115 Biogas Plant (Denmark), respectively. Both biogas plants use a mixture of manure

116 (pig and cattle) and organic waste (fat and flotation sludge from food industries) as

117 feedstock. As feedstock, dairy manure taken from Hashøj municipality (Denmark)

118 was used in this study. The dairy manure was mixed in one plastic barrel and was 
119 sieved, in order to remove the large solid particles, and then kept at $-18{ }^{\circ} \mathrm{C}$. Before

120 use as substrate in the batch experiment, the frozen manure was thawed and stored

121 at $4^{\circ} \mathrm{C}$ for $2-3$ days. The basic characteristics of the inoculum and feedstock were

122 analyzed and shown in Table 1.

Table 1 is here

\section{$124 \quad 2.2$ Experimental setup}

125 Both mesophilic and thermophilic inocula were incubated under four different am-

126 monia concentrations $\left(1,3,5\right.$ and $\left.7 \mathrm{~g} \mathrm{NH}_{4}{ }^{+}-\mathrm{N} \mathrm{L}^{-1}\right)$ with $\mathrm{NH}_{4} \mathrm{Cl}$ as ammonia source.

127 As batch reactors, vials with $118 \mathrm{~mL}$ total and $40 \mathrm{~mL}$ working volume, respectively

128 were used. The working volume contained $10 \mathrm{~mL}$ inoculum, $10 \mathrm{~mL}$ dairy manure

129 and $20 \mathrm{~mL}$ distilled water. After filling the content into the vials, butyl rubber stop-

130 pers and aluminum crimps were used to seal them. Then all the batch reactors were

131 flushed with nitrogen (flow rate $290 \mathrm{ml} / \mathrm{s}$ ) for $10 \mathrm{~min}$. Before the hydrogen injec-

132 tion, the same volumes as the injected hydrogen of gas were extracted from the

133 batch reactors to make sure the total pressure of all the batch reactors was the same.

134 After that, 19.5, 39 and $78 \mathrm{~mL}$ of hydrogen were introduced with syringes into

135 batch reactors to obtain different hydrogen partial pressure $(0.25,0.5$, and $1 \mathrm{~atm})$

136 for each ammonia level. Moreover, batch reactors without hydrogen addition, were

137 also included. Additionally, reactors only with inoculum were used as blanks to

138 evaluate the residual methane production. Two shaking incubators $\left(37 \pm 1{ }^{\circ} \mathrm{C}\right.$ and

$13955 \pm 1{ }^{\circ} \mathrm{C}, 180 \mathrm{rpm}$ ) were used for mesophilic and thermophilic batch reactors respec-

140 tively and each condition was evaluated in triplicates $(n=3)$. 


\section{$141 \quad 2.3$ Analytical methods}

142 Total solids (TS), volatile solids (VS), $\mathrm{pH}$, total ammonia and total Kjeldahl nitro-

143 gen (TKN) were measured according to APHA's Standard Methods (Federation \&

144 Association, 2005). The $\mathrm{pH}$ level of the batch reactors was determined by using

145 PHM99 LAB pH meter which was connected to the Gel pH electrode (pHC3105-8,

146 Radiometer analytical). The electrode was filled with a gel containing $\mathrm{KCl}$. Before

147 measuring samples, the $\mathrm{pH}$ meter was calibrated at the temperature of the corre-

148 sponding batch reactors. Shimadzu-14A gas chromatograph (GC) equipped with a

149 thermal FID detector with hydrogen as a carrier gas (Shimadzu, Kyoto, Japan) was

150 used to measure methane accumulation in the headspace of batch reactors. Hydro-

151 gen concentration in batch reactors was measured by using GC-TCD fitted with a

$1524.5 \mathrm{~m} \times 3 \mathrm{mms}-\mathrm{m}$ stainless column packed with Molsieve SA (10/80). Moreover, a

153 gas-chromatograph (GCTCD) equipped with a column of $1.1 \mathrm{~m} \times 3 / 16$ "Molsieve

154137 and $0.7 \mathrm{~m} \times 1 / 4$ " chromosorb 108 (MGC 82-12, Mikrolab A/S, Denmark) was

155 used to determine the biogas composition in the headspace of batch reactors. The

156 bottles were not vented during the whole experiment. The methane concentration

157 (in percentage) in the headspace was measured by GC with pressure. Thus, the ac-

158 cumulated methane was obtained by multiplying headspace volume of the batch

159 reactors $(78 \mathrm{ml})$ and the methane concentrations measured by GC. Additionally, the

160 accumulated volatile fatty acids (VFA) concentration of the batch reactors were

161 determined by using a gas-chromatograph (HP5890 series II) equipped with a flame

162 ionization detector and a FFAP fused silica capillary column, $(30 \mathrm{~m} \times 0.53 \mathrm{~mm}$ i.d.,

163 film thickness $1.5 \mu \mathrm{m}$ ), which uses nitrogen as carrier gas. 


\subsection{Calculations}

165

166

167

168

169

170

171

172

173

174

175

176

177

178

179

180

181

182

183 injection, when ammonia concentration increased from 1 to $7 \mathrm{~g} \mathrm{NH}_{4}{ }^{+}-\mathrm{N} \mathrm{L}^{-1}$, a de-

184 crease of $65.0 \%$ in the methane yield was observed at mesophilic condition. For the

185 mesophilic reactors adding hydrogen $(0.25,0.5$ and $1 \mathrm{~atm})$, inhibition caused by

\subsubsection{Calculation of methane production}

The hydrogen injected into the batch reactors was consumed by hydrogenotrophic methanogens to produce methane. Thus, the reactors with hydrogen addition had higher average methane yield compared to the reactors without hydrogen injection. Therefore, the calculation of subtracting the theoretical methane production from the introduced hydrogen in the batch reactors was made.

\subsubsection{Statistical analysis}

OriginLab program (OriginLab Corporation, Northampton, Massachusetts) was used for all the statistical analyses. For statistical analysis, one way Analysis of Variance (ANOVA) at 0.05 level was used. The effects of two factors (ammonia concentrations and hydrogen pressure) on methane production rate, methane production yield, VFA, pH level and carbon dioxide content were analyzed. All values presented are the means of independent triplicates $(\mathrm{n}=3) \pm \mathrm{SD}$.

\section{Results and discussion}

\subsection{Accumulated methane yield of the reactors}

In general, the methane yield decreased significantly $(\mathrm{p}<0.05, \mathrm{P}$ was ranging from $4.4 \times 10^{-8}$ to $1.3 \times 10^{-5}$ ) with the increase of ammonia levels under all different hydrogen partial pressures tested (Figure 1a). In detail, for the reactors without hydrogen increasing ammonia level was also detected. However, the inhibition was less pronounced when $\mathrm{H}_{2}$ was added. More specifically, the methane yields at ammonia 
188 level of $7 \mathrm{~g} \mathrm{NH}_{4}{ }^{+}-\mathrm{N} \mathrm{L}^{-1}$ were $42.7 \%, 41.0 \%$ and $48.3 \%$ lower compared $1 \mathrm{~g} \mathrm{NH}_{4}{ }^{+}-\mathrm{N}$

$189 \mathrm{~L}^{-1}$ for hydrogen additions of $0.25,0.5$ and 1 atm respectively (Figure 1a).

\section{Figure 1 is here}

191 Similarly, at thermophilic condition, the methane yield decreased by $44.2 \%$ in the

192 reactors without hydrogen injection, when ammonia was increased from 1 to $7 \mathrm{~g}$

$193 \mathrm{NH}_{4}{ }^{+}-\mathrm{N} \mathrm{L}^{-1}$ (Figure 1a). Likewise the mesophilic conditions, inhibition was also

194 less serious for the reactors with hydrogen. In addition, the highest methane yield

195 at ammonia concentration of $7 \mathrm{~g} \mathrm{NH}_{4}{ }^{+}-\mathrm{N} \mathrm{L}^{-1}$ was observed under 0.5 atm initial

196 hydrogen partial pressure both at mesophilic and thermophilic conditions. An inter-

197 esting observation was that the methane yield in the thermophilic reactor was high-

198 er than that in the mesophilic reactors with ammonia concentration of $7 \mathrm{~g} \mathrm{NH}_{4}{ }^{+}-\mathrm{N}$

$199 \mathrm{~L}^{-1}$ regardless of the initial hydrogen partial pressure. This is in particular noticea-

200 ble as thermophilic methanogenesis is in general considered more ammonia sensi201 tive.

202 At high ammonia concentration $\left(7 \mathrm{~g} \mathrm{NH}_{4}{ }^{+}-\mathrm{N} \mathrm{L}^{-1}\right)$ even after subtracting the theoret203 ical methane production from the introduced hydrogen (which was completely con204 sumed in all the reactors) in the batch reactors higher methane production was ob205 served, indicating that the tolerance to ammonia toxicity was promoted by hydrogen

206 addition. Therefore, the results confirmed that the hydrogen enriched biogas up207 grading process was more resistant to high ammonia levels compared to the con208 ventional AD processes.

209 Ammonia is considered as an inhibitor of slowing down the growth and metabolic 210 rates, therefore we calculated the methane production rates at different initial hy211 drogen partial pressures $\left(0,0.25,0.5\right.$ and 1 atm) under 1 and $7 \mathrm{~g} \mathrm{NH}_{4}^{+}-\mathrm{N} \mathrm{L}^{-1}$ in 
212 mesophilic and thermophilic conditions (Figure 1b). The length of time for calculat-

213 ing methane production rate was from the beginning to the day that stable accumu-

214 lated methane production was obtained (26 days, the whole length of the process

215 was 48 days). The same tendency as for the methane yields, were shown for the

216 methane production rates with ammonia concentration increase. In detail, the most

217 serious inhibition occurred in the reactors without hydrogen injection at $7 \mathrm{~g} \mathrm{NH}_{4}{ }^{+}-\mathrm{N}$

$218 \mathrm{~L}^{-1}$ both in mesophilic (56.7\% lower) and thermophilic (53.4\% lower) conditions,

219 which was in agreement with the methane yield result. Furthermore, at $7 \mathrm{~g} \mathrm{NH}_{4}{ }^{+}-\mathrm{N}$

$220 \mathrm{~L}^{-1}$, the highest methane production rate was also achieved under 0.5 atm initial

221 hydrogen partial pressure both at mesophilic $\left(7.7 \mathrm{~mL} \mathrm{CH}_{4}(\mathrm{~L} \cdot \mathrm{h})^{-1}\right)$ and thermo-

222 philic $\left(13.4 \mathrm{~mL} \mathrm{CH}_{4}(\mathrm{~L} \cdot \mathrm{h})^{-1}\right)$ conditions.

Figure 2 is here

224 In general, the methane yield decreased with the increase of ammonia levels (Figure

225 2). In detail, when ammonia concentration was increased to 5 and $7 \mathrm{~g} \mathrm{NH}_{4}{ }^{+}-\mathrm{N} \mathrm{L}^{-1}$,

226 the accumulated methane yield decreased significantly $\left(p<0.05, p=8.7 \times 10^{-7}\right)$ in

227 mesophilic condition. In thermophilic condition, the methane yield was affected

228 less by the increasing ammonia levels compared to the mesophilic reactors.

229 Both the results of methane yield and production rate indicated that the hydrogen

230 based biogas upgrading process can still function at high ammonia level and was

231 more tolerant compared to the conventional AD processes, though ammonia inhibi-

232 tion occurred. The highest methane production yield was achieved under $0.5 \mathrm{~atm}$

233 hydrogen partial pressure in batch reactors at high ammonia levels. However, intro-

234 ducing hydrogen to anaerobic biogas reactors could also lead to negative effect at

235 least at the initial phase, until the hydrogen consumption rate by hydrogentrophic 
236 methanogens is equal or greater compared with the hydrogen production and injec-

237 tion rate which may make a balance process again (Luo \& Angelidaki, 2013a).

238 Based on theoretical considerations but also by experimental proof, the increase of

239 the hydrogen partial pressure in biogas reactors could cause decreased degradation

240 of VFA, leading to process disturbance or break down (Fukuzaki et al., 1990; Luo

241 et al., 2012; Siriwongrungson et al., 2007). Thus, the relatively lower methane yield

242 and methane production rate at $1 \mathrm{~atm}$ (compared with $0.5 \mathrm{~atm}$ ) indicated that the

243 threshold of hydrogen partial pressure could be between 0.5 and 1 atm for causing

244 disturbance of the process in the current study. Furthermore, an interesting observa-

245 tion was that thermophilic batch reactors were more resistant under high ammonia

246 levels (5 and $7 \mathrm{~g} \mathrm{NH}_{4}{ }^{+}-\mathrm{N} \mathrm{L}^{-1}$ ), compared with mesophilic reactors (0.5 atm). Free

247 ammonia $\left(\mathrm{NH}_{3}\right)$ has been considered to be the main toxic compound causing am-

248 monia inhibition and high temperature will increase the free ammonia levels.

249 Therefore, the result of the current study was contradictory to some previous stud-

250 ieswhich reported that mesophilic methanogenesis is more resistant to high ammo-

251 nia loads compared to the thermophilic process due to the lower free ammonia con-

252 centrations (Chen et al., 2008; Fotidis et al., 2013). However, it was also (Wang et

253 al., 2015a) previously reported that hydrogenotrophic thermophilic methanogens

254 can tolerate higher ammonia and free ammonia concentrations compared to meso-

255 philic methanogens, which was in agreement with the result of this study. Moreo-

256 ver, in a previous study, thermophilic hydrogenotrophic methanogenic enrichment

257 cultures were shown to be more efficient for methane production $\left(122 \mathrm{~mL} \mathrm{CH}_{4}(\mathrm{~g}\right.$

258 VSS h) ${ }^{-1}$ higher) compared to mesophilic enrichment cultures due to the higher

259 rates of digestion, which could be another explanation (Luo \& Angelidaki, 2012). 
260 The discrepancy on the ammonia tolerance at mesophilic or thermophilic conditions

261 could very well explained by the mechanism of ammonia inhibition. As it is as-

262 sumed that free ammonia concentration $\left(\mathrm{NH}_{3}\right)$ is the active form for inhibition,

263 which of course would constitute the thermophilic processes more susceptible for

264 inhibition. However, this does not exclude the possibility that the thermophilic or-

265 ganisms are more tolerant to free ammonia $\left(\mathrm{NH}_{3}\right)$ levels. This could also be sup-

266 ported by the evolutionary pressure in thermophiles to develop tolerance to free

267 ammonia levels.

268 The results of the current study that high ammonia concentration can inhibit the

269 hydrogen enriched biogas production and upgrading processes by lowering the me-

270 thane yield should be noticed especially when substrates containing high ammonia

271 levels are used. Moreover, one of the challenges that the innovative AD process has

272 is the increasing of $\mathrm{pH}$ due to the consumption of carbon dioxide, which subse-

273 quently will increase the free ammonia concentration and enhance the ammonia

274 inhibition. Therefore, some sustainable and practical methods for counteracting

275 ammonia inhibition on such processes are needed in the future. Controlling $\mathrm{pH}$ lev-

276 els by co-digestion with appropriate low $\mathrm{pH}$ substrates could be an optional solution.

277 For example, in a previous study, Luo and Angelidaki (2013a) maintained the pH

278 level in an optimal range for anaerobic digestion in the biogas reactor with addition

279 of hydrogen by co-digestion of manure and acidic whey.

\section{$280 \quad 3.2$ VFA Accumulation and pH levels}

281 Generally, the total VFA concentrations of the reactors increased with the increas282 ing ammonia levels. The reactors with initial hydrogen partial pressure of $0.5 \mathrm{~atm}$ 283 had the lowest VFA concentrations, indicating a healthy AD process without VFA 
284 accumulation and inhibition of methanogenesis, which was in agreement with the

285 results of the methane yield (Figure 3). Specifically, under mesophilic condition

286 and ammonia levels of $7 \mathrm{~g} \mathrm{NH}_{4}{ }^{+}-\mathrm{N} \mathrm{L}^{-1}$, the VFA concentrations were 1.3 and $1.6 \mathrm{~g}$

$287 \mathrm{~L}^{-1}$ at 0 and $1 \mathrm{~atm}$ of hydrogen partial pressure respectively, which were significant-

288 ly $\left(\mathrm{p}<0.05, \mathrm{p}=1.7 \times 10^{-8}\right)$ higher compared with ones at 0.25 and 0.5 atm (Figure $\left.3 \mathrm{a}\right)$.

289 Additionally, at 0.5 atm of hydrogen partial pressure, total VFA at all tested ammo290 nia levels were below $0.4 \mathrm{~g} \mathrm{~L}^{-1}$ (Figure 3a) and similar results were obtained under 291 thermophilic condition.

293 High hydrogen partial pressure is considered to cause inhibition of propionate and 294 butyrate degradation (Fukuzaki et al., 1990; Siriwongrungson et al., 2007). Howev295 er, at shaking speed of $100 \mathrm{rpm}$ under $1 \mathrm{~atm}$ of hydrogen partial pressure, no inhibi296 tion of either propionate or butyrate degradation was observed (Luo et al., 2012). 297 The hydrogen's slow mass transfer from gas to the liquid phase combined with the 298 fast consumption rate of the dissolved hydrogen by the hydrogenotrophic methano299 gens, was the procedure for keeping dissolved hydrogen level low for efficient deg300 radation of propionate and butyrate (Fukuzaki et al., 1990). On the contrary in the 301 current study, the relatively higher shaking speed (180 rpm) applied may cause fast 302 hydrogen transfer to the liquid phase resulting in more dissolved hydrogen in liq303 uid, and along with the high ammonia level $\left(7 \mathrm{~g} \mathrm{NH}_{4}{ }^{+}-\mathrm{N} \mathrm{L}^{-1}\right)$ could be the reason of 304 the increase of the VFA concentrations at 1 atm of hydrogen partial pressure. On 305 the contrary for the middle hydrogen partial pressures $(0.25$ and $0.5 \mathrm{~atm})$, lower 306 VFA concentrations were obtained. The reason for the less VFA accumulation at 
$307 \quad 0.25$ and 0.5 atm could be the lower dissolved hydrogen level in the liquid and also

308 the resistance to ammonia toxicity.

309 The $\mathrm{pH}$ levels in both mesophilic and thermophilic batch reactors were shown in

310 Figure 4. At 0 and 1 atm of hydrogen partial pressure, the pH decreased from 7.95

311 to around $7.80\left(7 \mathrm{~g} \mathrm{NH}_{4}{ }^{+}-\mathrm{N} \mathrm{L}^{-1}\right)$, while at $0.5 \mathrm{~atm}$, the $\mathrm{pH}$ levels under different

312 ammonia concentrations increased from 7.95 to around 8.10. During anaerobic di-

313 gestion of cattle manure, several substances such as ammonia, bicarbonate, and

314 VFA could affect pH levels (Batstone et al., 2002). Therefore, at ammonia concen-

315 tration of $7 \mathrm{~g} \mathrm{NH}_{4}{ }^{+}-\mathrm{N} \mathrm{L}^{-1}$, the significant increase $\left(\mathrm{p}<0.05, \mathrm{p}=6.9 \times 10^{-5}\right.$ at mesophilic,

$316 \mathrm{p}=2 \times 10^{-5}$ at thermophilic) of $\mathrm{pH}$ at 0.25 and $0.5 \mathrm{~atm}$ was caused by the consumption

317 of bicarbonate which was used by hydrogenotrophic methanogens for methane 318 production (Luo \& Angelidaki, 2013a; Mu et al., 2006). However, the relatively 319 lower $\mathrm{pH}$ at $1 \mathrm{~atm}$ and $7 \mathrm{~g} \mathrm{NH}_{4}{ }^{+}-\mathrm{N} \mathrm{L}^{-1}$, was due to the accumulation of VFA.

Figure 4 is here

\section{$321 \quad 3.3$ Biogas composition}

322 In the mesophilic reactors, the carbon dioxide content decreased with the increasing 323 of hydrogen partial pressure at ammonia concentration of $7 \mathrm{~g} \mathrm{NH}_{4}^{+}-\mathrm{N} \mathrm{L}^{-1}$ (Figure

324 5a). Nevertheless, no further decrease was observed when hydrogen partial pressure 325 was higher than $0.5 \mathrm{~atm}$. It was consistent with previous observation in hydrogen 326 enriched biogas production and upgrading process at low ammonia load $(\leq 2 \mathrm{~g}$ $327 \mathrm{NH}_{4}{ }^{+}-\mathrm{N} \mathrm{L} \mathrm{L}^{-1}$ ) (Luo et al., 2012). Although similar trend was observed in the thermo328 philic reactors for initial hydrogen partial pressures of 0 and 0.5 atm, the carbon 329 dioxide content further decreased at higher hydrogen partial pressure (1 atm) (Fig330 ure 5a). This could be due to the higher conversion rates and activity of the micro- 
331 organisms at thermophilic temperature which permits a faster removal of the hy-

332 drogen and avoids accumulation of VFA. The results again confirmed that the hy-

333 drogen enriched biogas upgrading processes can still function at high ammonia

334 concentration.

336 Comparatively, with fixed hydrogen pressure, the ammonia concentration had no 337 significant influence on carbon dioxide content, both in mesophilic and thermo338 philic conditions ( $\mathrm{p}>0.05, \mathrm{p}=0.135$ at mesophilic, $\mathrm{p}=0.138$ at thermophilic) (Figure 339 5b). In detail, the carbon dioxide content was $38.1 \%$ and $40.0 \%$ (mesophilic and 340 thermophilic, respectively) at $7 \mathrm{~g} \mathrm{NH}_{4}{ }^{+}-\mathrm{N} \mathrm{L}^{-1}$ without adding hydrogen which was 341 in accordance with previously reported (Lindeboom et al., 2012). Meanwhile the 342 methane content was around $80 \%$ when hydrogen was added, as it was reacting 343 with carbon dioxide to produce methane. According to Figure 1a and 1b, the me344 thane yield had a significant $(\mathrm{p}<0.05)$ decreasing at high ammonia levels. On the 345 contrary, at the same ammonia concentration $\left(7 \mathrm{~g} \mathrm{NH}_{4}{ }^{+}-\mathrm{N} \mathrm{L}^{-1}\right)$ the methane content 346 increased (or carbon dioxide content decreased) in the reactors with hydrogen injec347 tion, which indicated that hydrogentrophic methanogens might be more resistant to 348 high ammonia levels compared to acetoclastic methanogens in the hydrogen en349 riched biogas production and upgrading processes. 


\section{Conclusions}

351 The results of the current study indicated that high ammonia concentration can 352 inhibit the hydrogen enriched biogas production and upgrading processes by 353 lowering the methane yield. Nevertheless, the ammonia concentration had no 354 significant effect on the biogas composition in such processes. It also implied that 355 the hydrogen enriched production and upgrading processes was more tolerant to 356 high ammonia concentrations compared with conventional AD process. Moreover, 357 thermophilic methanogens seemed to perform better compared with mesophilic 358 methanogens under high ammonia levels $\left(5\right.$ and $\left.7 \mathrm{~g} \mathrm{NH}_{4}{ }^{+}-\mathrm{N} \mathrm{L}^{-1}\right)$. The current study 359 was the first time to quantify ammonia toxicity for the hydrogen enriched biogas 360 production and upgrading processes. Therefore, some sustainable and practical 361 methods for counteracting ammonia inhibition on such processes (e.g., $\mathrm{pH}$ control 362 or co-digested with low $\mathrm{pH}$ substrate) are needed in the future.

\section{Acknowledgements}

364 The authors would like to acknowledge financial support from The Danish Council 365 for Independent Research (DFF-1335-00142) and DTU PoC Fond (31176).

367 References

368 Angelidaki, I., Ahring, B. 1994. Anaerobic thermophilic digestion of manure at 369 different ammonia loads: effect of temperature. Water Research, 28(3), 727-731

370 Angelidaki, I., Ahring, B. 1993. Thermophilic anaerobic digestion of livestock waste: 371 the effect of ammonia. Applied Microbiology and Biotechnology, 38(4), 560-564.

372 Angelidaki, I., Karakashev, D., Batstone, D.J., Plugge, C.M., Stams, A.J. 2011. 373 Biomethanation and its potential. Methods Enzymol, 494, 327-351. 
374 Batstone, D.J., Keller, J., Angelidaki, I., Kalyuzhnyi, S., Pavlostathis, S., Rozzi, A., 375 Sanders, W., Siegrist, H., Vavilin, V. 2002. The IWA Anaerobic Digestion Model 376 No 1(ADM 1). Water Science \& Technology, 45(10), 65-73.

377 Chen, Y., Cheng, J.J., Creamer, K.S. 2008. Inhibition of anaerobic digestion process: a 378 review. Bioresource Technology, 99(10), 4044-4064.

379 Federation, W.E., Association, A.P.H. 2005. Standard methods for the examination of 380 water and wastewater. American Public Health Association (APHA): Washington, $381 \quad D C, U S A$.

382 Fotidis, I.A., Karakashev, D., Kotsopoulos, T.A., Martzopoulos, G.G., Angelidaki, I. 383 2013. Effect of ammonium and acetate on methanogenic pathway and methanogenic 384 community composition. FEMS Microbiology Ecology, 83(1), 38-48.

385 Fukuzaki, S., Nishio, N., Shobayashi, M., Nagai, S. 1990. Inhibition of the fermentation 386 of propionate to methane by hydrogen, acetate, and propionate. Applied and 387 Environmental Microbiology, 56(3), 719-723.

388 Gallert, C., Bauer, S., Winter, J. 1998. Effect of ammonia on the anaerobic degradation 389 of protein by a mesophilic and thermophilic biowaste population. Applied $390 \quad$ Microbiology and Biotechnology, 50(4), 495-501.

391 Hafner, S.D., Bisogni, J.J. 2009. Modeling of ammonia speciation in anaerobic digesters. $392 \quad$ Water Research, 43(17), 4105-4114.

393 Lindeboom, R.E., Weijma, J., van Lier, J.B. 2012. High-calorific biogas production by 394 selective $\mathrm{CO} 2$ retention at autogenerated biogas pressures up to 20 bar. 395 Environmental Science \& Technology, 46(3), 1895-1902. 
396 Luo, G., Angelidaki, I. 2013a. Co-digestion of manure and whey for in situ biogas 397 upgrading by the addition of $\mathrm{H} 2$ : process performance and microbial insights. 398 Applied Microbiology and Biotechnology, 97(3), 1373-1381.

399 Luo, G., Angelidaki, I. 2013b. Hollow fiber membrane based H2 diffusion for efficient 400 in situ biogas upgrading in an anaerobic reactor. Applied Microbiology and $401 \quad$ Biotechnology, 97(8), 3739-3744.

402 Luo, G., Angelidaki, I. 2012. Integrated biogas upgrading and hydrogen utilization in an 403 anaerobic reactor containing enriched hydrogenotrophic methanogenic culture. 404 Biotechnology and Bioengineering, 109(11), 2729-2736.

405 Luo, G., Johansson, S., Boe, K., Xie, L., Zhou, Q., Angelidaki, I. 2012. Simultaneous 406 hydrogen utilization and in situ biogas upgrading in an anaerobic reactor. 407 Biotechnology and Bioengineering, 109(4), 1088-1094.

408 Mu, Y., Yu, H.Q., Wang, Y. 2006. The role of $\mathrm{pH}$ in the fermentative H 2 production 409 from an acidogenic granule-based reactor. Chemosphere, 64(3), 350-358.

410 Nielsen, H.B., Angelidaki, I. 2008. Strategies for optimizing recovery of the biogas 411 process following ammonia inhibition. Bioresource Technology, 99(17), 7995-8001.

412 Rajagopal, R., Massé, D.I., Singh, G. 2013. A critical review on inhibition of anaerobic 413 digestion process by excess ammonia. Bioresource Technology, 143, 632-641.

414 Siriwongrungson, V., Zeng, R.J., Angelidaki, I. 2007. Homoacetogenesis as the 415 alternative pathway for $\mathrm{H} 2$ sink during thermophilic anaerobic degradation of 416 butyrate under suppressed methanogenesis. Water Research, 41(18), 4204-4210.

417 Sprott, G.D., Patel, G.B. 1986. Ammonia toxicity in pure cultures of methanogenic 418 bacteria. Systematic and Applied Microbiology, 7(2), 358-363. 
419 Stams, A.J., Plugge, C.M. 2009. Electron transfer in syntrophic communities of

$420 \quad$ anaerobic bacteria and archaea. Nature Reviews Microbiology, 7(8), 568-577.

421 Wang, H., Fotidis, I.A., Angelidaki, I. 2015. Ammonia effect on hydrogenotrophic

422 methanogens and syntrophic acetate-oxidizing bacteria. FEMS Microbiology

$423 \quad$ Ecology, 91(11), fiv130.

424 Yenigün, O., Demirel, B. 2013. Ammonia inhibition in anaerobic digestion: a review.

$425 \quad$ Process Biochemistry, 48(5), 901-911.

426

427

428

429

430

431

432

433

434

435

436

437

438

439

440

441

442 
443 Table and figure captions

444 Table 1. Characteristics of the inoculum and the dairy manure.

445 Figure 1. Methane yield (a) and methane production rate (b) as a function of hy446 drogen partial pressure.

447 Figure 2. Methane yield as a function of ammonia concentrations at hydrogen par448 tial pressure of $0.5 \mathrm{~atm}$.

449 Figure 3. Total VFA accumulation under different hydrogen partial pressure (a) 450 and under different ammonia concentrations (b).

451 Figure 4. $\mathrm{pH}$ levels at different hydrogen partial pressure under $7 \mathrm{~g} \mathrm{NH}_{4}{ }^{+}-\mathrm{N} \mathrm{L}^{-1}$ (a) 452 and $\mathrm{pH}$ under different ammonia concentrations at hydrogen partial pressure of 0.5 453 atm (b).

454 Figure 5. Carbon dioxide content under different hydrogen partial pressure (a) and 455 under different ammonia concentrations (b).

456

457

458

459

460

461

462 
Table 1. Characteristics of the inoculum and the dairy manure

\begin{tabular}{llll}
\hline Parameter (unit) & $\begin{array}{l}\text { Mesophilic } \\
\text { Inoculum }\end{array}$ & $\begin{array}{l}\text { Thermophilic } \\
\text { Inoculum }\end{array}$ & Dairy manure \\
\hline Density $\left(\mathrm{g} \cdot \mathrm{L}^{-1}\right)$ & $1003 \pm 0.17$ & $1003 \pm 0.52$ & $1002 \pm 0.78$ \\
$\mathrm{TS}\left(\mathrm{g} \cdot \mathrm{L}^{-1}\right)$ & $48.04 \pm 0.24$ & $31.24 \pm 0.17$ & $86.93 \pm 0.00$ \\
$\mathrm{VS}\left(\mathrm{g} \cdot \mathrm{L}^{-1}\right)$ & $28.42 \pm 0.00$ & $16.70 \pm 0.00$ & $63.30 \pm 0.01$ \\
$\begin{array}{l}\text { Total Kjeldahl nitrogen }(\mathrm{g} \\
\mathrm{N} \mathrm{L}\end{array}$ & $4.61 \pm 0.21$ & $4.23 \pm 0.16$ & $3.51 \pm 0.13$ \\
Ammonia $\left(\mathrm{g} \mathrm{NH}{ }^{+}{ }^{-} \mathrm{N} \cdot \mathrm{L}^{-1}\right)$ & $3.63 \pm 0.09$ & $3.04 \pm 0.05$ & $2.10 \pm 0.08$ \\
Total VFA $\left(\mathrm{mg} \mathrm{L}^{-1}\right)$ & $705.6 \pm 27.91$ & $900.8 \pm 24.40$ & $3781 \pm 137.14$ \\
$\mathrm{pH}$ & 7.78 & 7.83 & 8.06 \\
\hline
\end{tabular}

“ \pm " means standard deviation and all values presented are the means of independent triplicates $(n=3)$ 

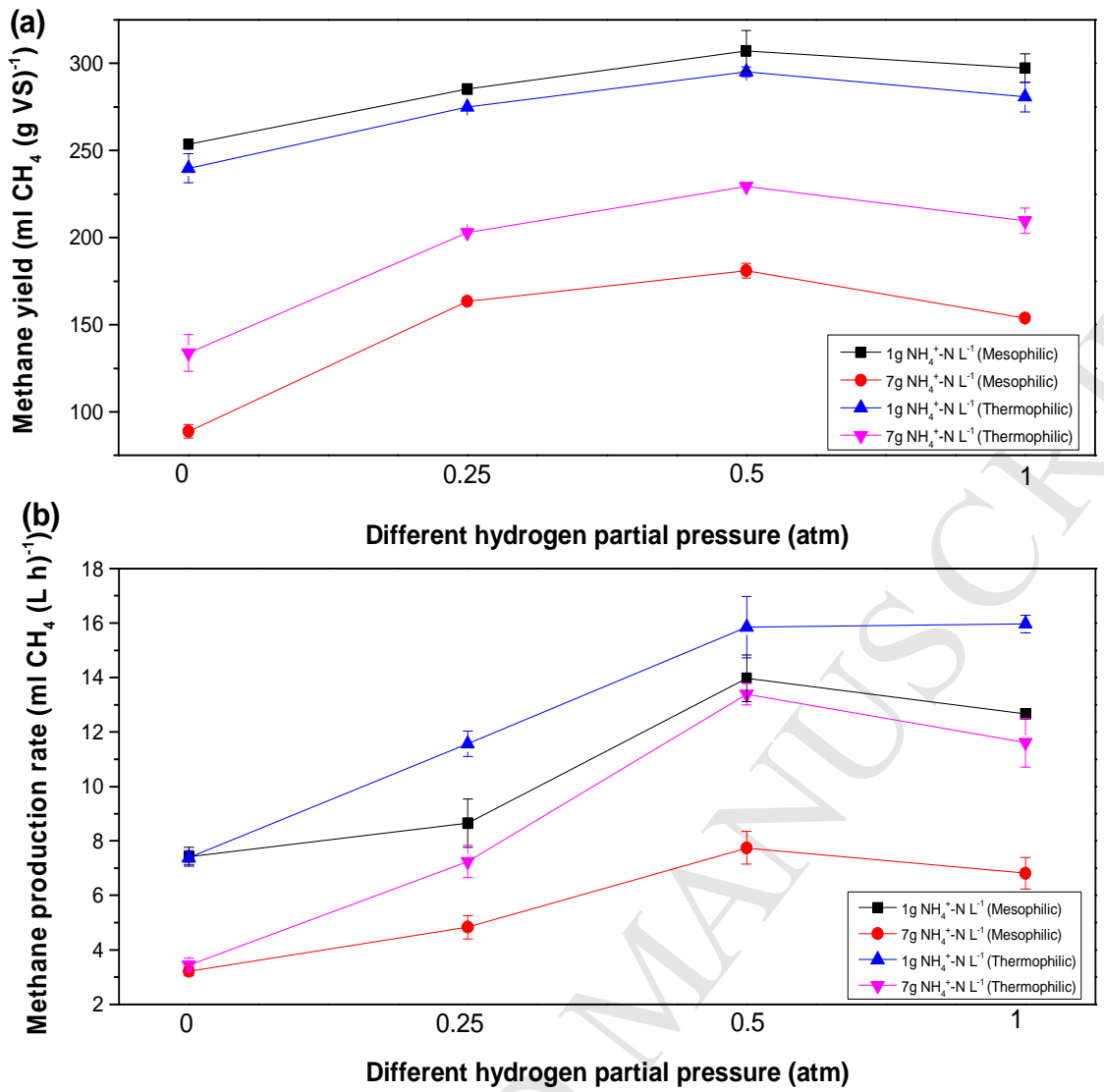

Figure 1. Methane yield (a) and methane production rate (b) as a function of hydrogen partial pressure. 


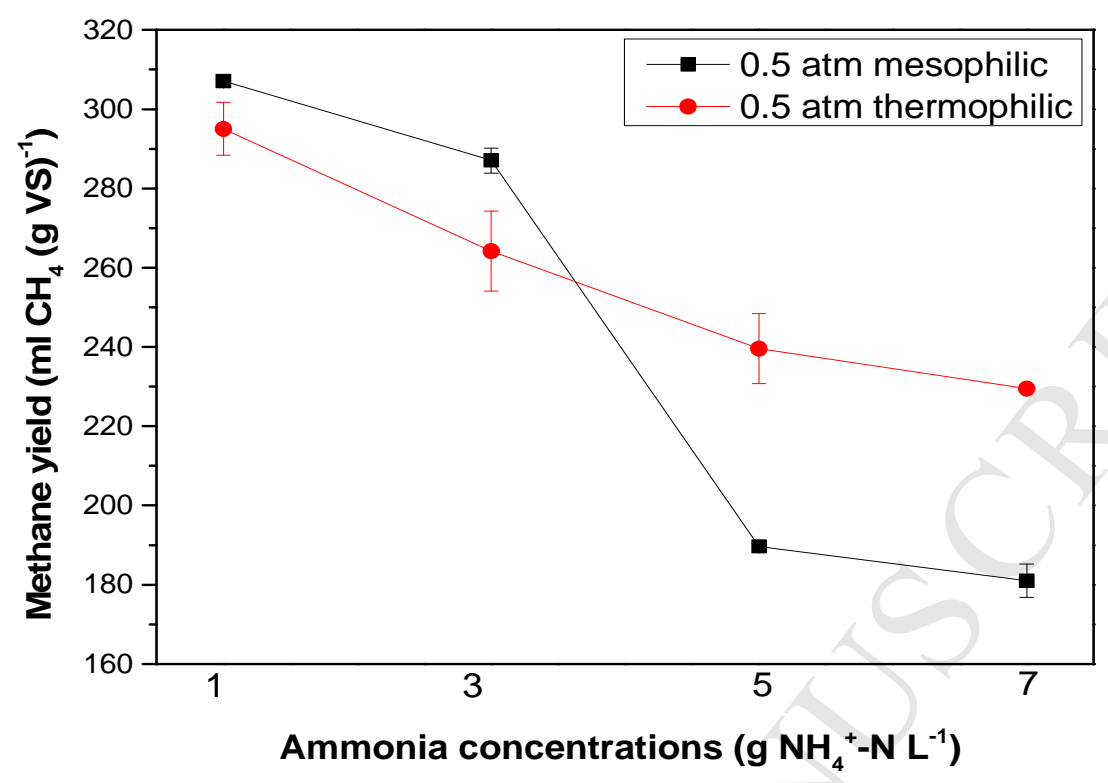

Figure 2. Methane yield as a function of ammonia concentrations at hydrogen partial pressure of $0.5 \mathrm{~atm}$. 

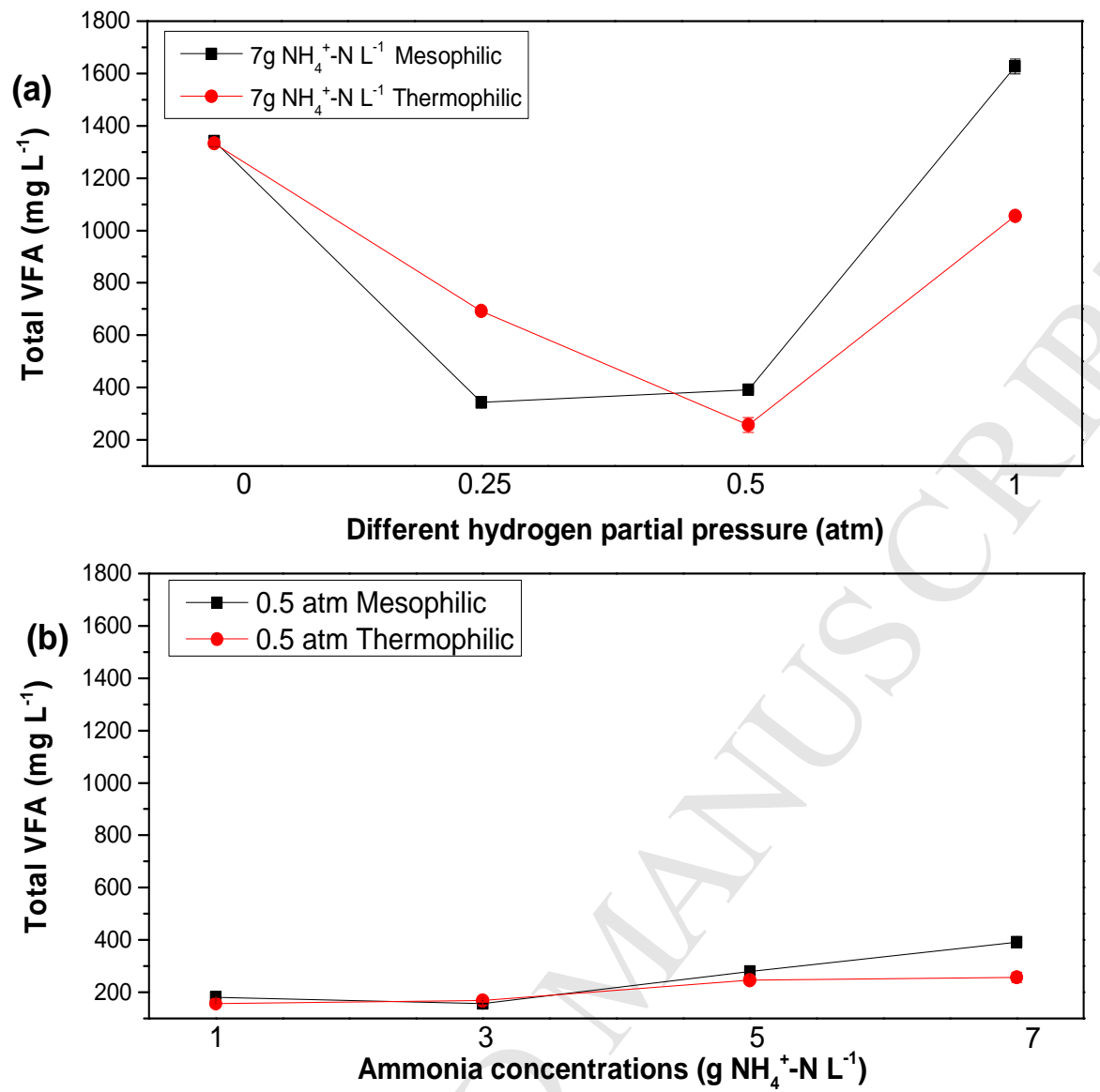

Figure 3. Total VFA accumulation under different hydrogen partial pressure (a) and under different ammonia concentrations (b). 

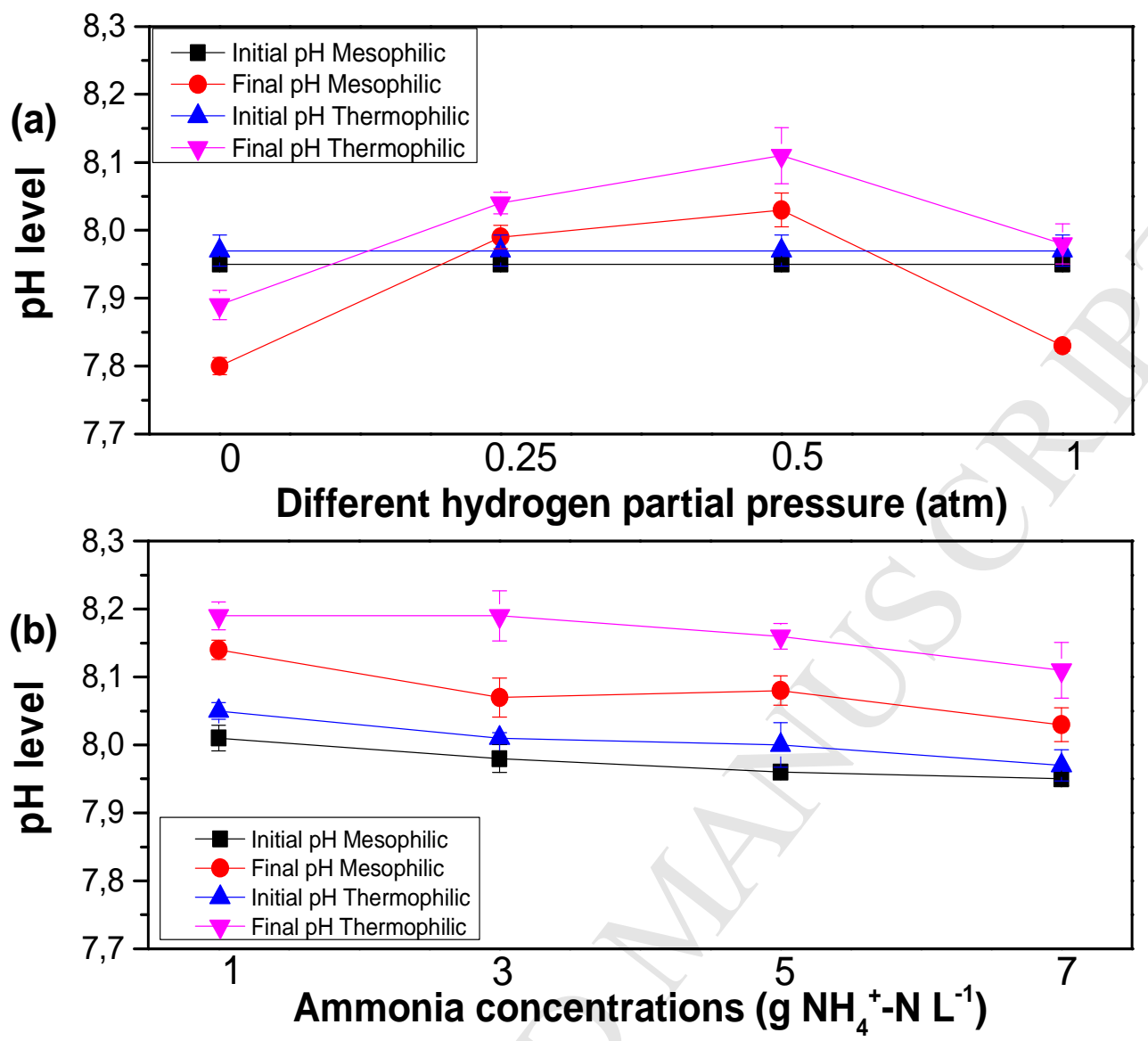

Figure 4. $\mathrm{pH}$ levels at different hydrogen partial pressure under $7 \mathrm{~g} \mathrm{NH}_{4}{ }^{+}-\mathrm{N} \mathrm{L}^{-1}$ (a) and $\mathrm{pH}$ under different ammonia concentrations at hydrogen partial pressure of $0.5 \mathrm{~atm}$ (b). 

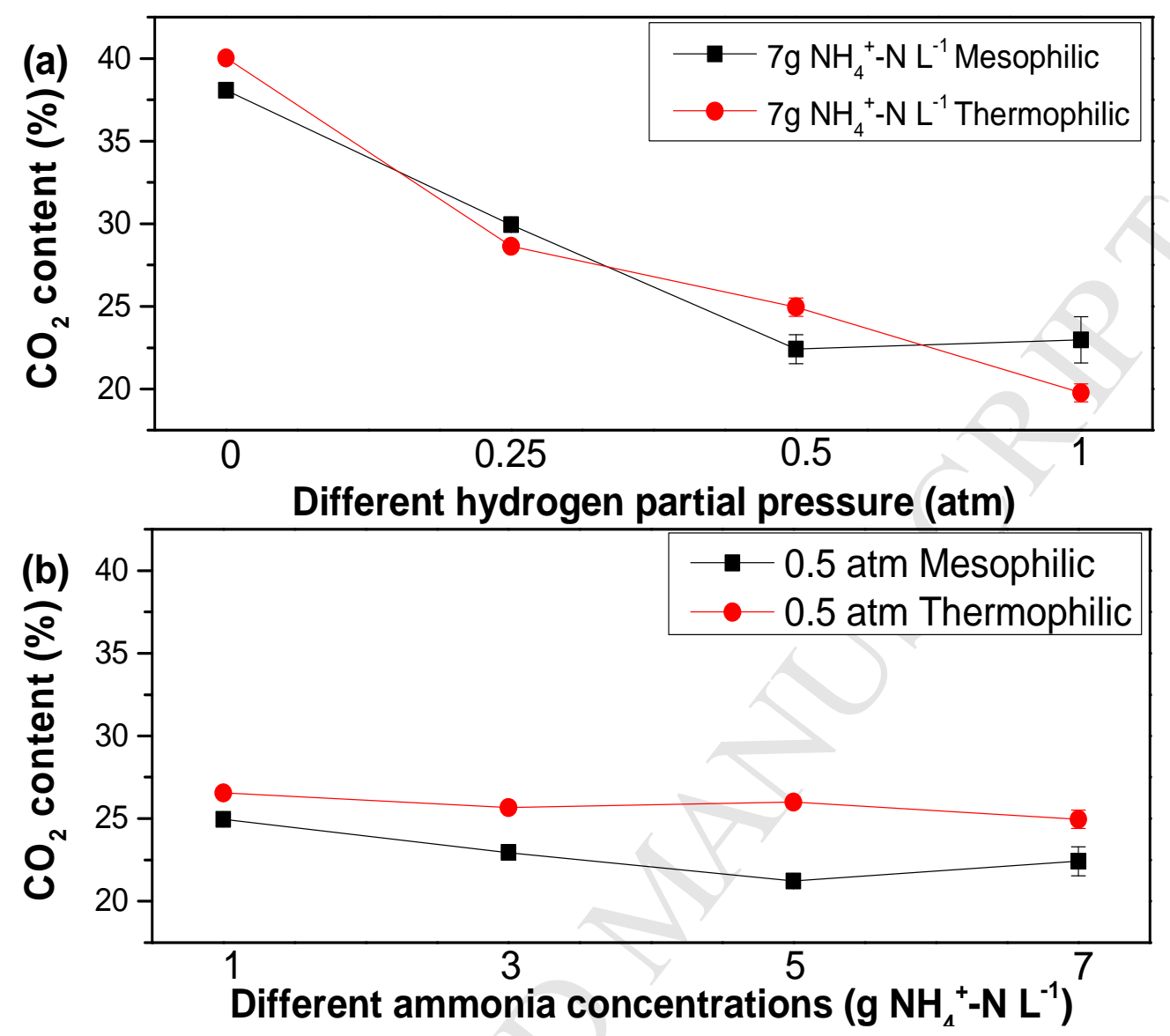

Figure 5. Carbon dioxide content under different hydrogen partial pressure (a) and under different ammonia concentrations (b). 


\section{Highlights}

- High ammonia concentration inhibited hydrogen enriched biogas upgrading processes.

- High ammonia concentration can lower the methane yield.

- The ammonia concentration had no significant effect on the biogas composition.

- Hydrogenotrophic archaea were more resistant to ammonia toxicity.

- The ammonia toxicity was alleviated at thermophilic condition. 